\title{
超音波検査を用いた下肢血流検査
}

\author{
九州大学整形外科 \\ 末 永 英慈・野口康男 \\ 神宮司 誠也·浦 裕 正 \\ 高 杉 紳一郎・岩 本 幸 英
}

\section{Postoperative Findings for Lower Extremity Blood Flow with Duplex Ultrasonography}

\author{
Eiji Suenaga, Yasuo Noguchi, Seiya Jingushi, \\ Hiromasa Miura, Shinichiro Takasugi, and Yukihide Iwamoto \\ Department of Orthopaedic Surgery, Kyusyu University
}

\begin{abstract}
We observed the blood flow in the femoral vein and greater saphenous vein using color Doppler ultrasonography after orthopaedic lower extremity operation. Between March 1999 and February 2000, 108 patients underwent 18 total knee arthroplasties, 46 total hip arthroplasties, and 44 hip osteotomies. We performed venous duplex ultrasonography twice on both lower extremities of all patients at a mean of seven days (range; five to eight days) and fourteen days (range; twelve to fifteen days) postoperatively. There were 25 male and 83 female patients with a mean age of 55 years (age range; 20 to 84 years). Greater saphenous blood flow increased in 49 (23 percent) of the 216 extremities. Thirty-two were ipsilateral, and 17 were contralateral. We suggest that these findings indicate asymptomatic deep venous thrombosis. With the numbers available, we were able to detect an association between an increase in the greater saphenous venous flow and procedures $(\mathrm{P}<0.01)$. This study provides further evidence of the importance of prophylaxis against thromboembolism following total arthroplasty.
\end{abstract}

Key words : deep venous thrombosis（深部静脈血栓症）, ultrasonography（超音波検査）, osteotomy（骨切り術）

\section{はじめに}

整形外科手術後の深部静脈血栓症（以下 DVT）の 発生は, 致死性肺塞栓症の原因となるため早期診断, 治療が必要である ${ }^{12}$. その危険因子としては，高齢， 下肢外傷, 長期臥床, 肥満, 血栓の既往, 楼血性心不 全，悪性腫揚，妊娠，経口避妊薬の使用などがあげら れている゙!。

DVT の診断方法は下肢静脈造影, 下肢静脈エコー, RI 静脈造影, MR venography などがあるが，一般
的には下肢静脈エコーといわゆる gold standard の 下肢静脈造影検査が用いられている ${ }^{6}$. 下肢静脈エコー 検査は下肢静脈造影に比へ，手技に習熟することが必 要であることに加え，下腿静脈血栓の診断能は落ちる が，非侵襲的で，コストが低く，持ち運びが出来，ベッ ドサイドで検査可能といった利点がある゙ ${ }^{3}$.さらに工 コーのカラーモードでは血管内の血流速度を色調の信 号変化で表示する機能があり, 経時的な血流の変化を 観察できるが，血栓の有無を確認する際に用いられる ことがほとんどである. 
そこで，今回我々は，エコーのカラーモードを用い て整形外科下肢手術後の DVT 発症例の血行動態の変 化を調查し，検討を加えた。

\section{対象および方法}

対象は 1999 年 3 月より 2000 年 2 月までに, 当科で 股関節・滕関節への人工関節手術あるいは骨切り術を 施行した 108 人 216 肢で，男性 25 人女性 83 人，平均 年齢は 55 歳である。疾患は変形性関節症 73 例，大腿 骨頭壊死症 22 例，慢性関節りウマチ 10 例，頸部骨折 3 例であり，人工膝関節置換術（以下 TKR）を 18 例， 人工股関節置換術（以下 $\mathrm{THR}$ ）あるいは股関節骨切 り術を 90 例に施行した。全例とも DVT に対する抗 凝固療法などの予防は行っていない.

術後 2 回, 5 8 日目と 12 15 日目にベッドサイ ドにて仰臥位で両側鼠径部のみを Aloka エコーカメ ラSSD-2000を用いて検査した， $7.5 \mathrm{MHz}$ の電子リニ アプローブを用いて，大腿静脈が深大腿静脈と合流す る部位がモニターの中央にくるように血管の長軸像を 表示させ，カラーモードで血管内の血流を観察した。 カラーモードではプローブに向かってくる血流成分を 赤系統，遠ざかる血流成分を青系統で表示するように 設定してあるが，高速血流になればそれぞれ黄色，水 色と表示されるため，高速流を認めたものを血流増加 状態と判定した。さらに，大伏在静脈は大腿内側の表 在部を通り深大腿静脈合流部のさらに上流で合流して おり，プローブで大腿内側を検索すると容易に確認で きるため，同様に検査した．

\section{症 例 供 覧}

実際にDVTの診断が得られた症例を示す，症例 は 74 歳女性, 左大腿骨澒部骨折に対し, 人工骨頭 置換術を施行した。術後より手術側の下腿周径が非 手術側に比べ $2 \mathrm{~cm}$ 増加している所見が認められてい たが，明らかな压痛などはなく，Homans 徵候や Lowenberg test も除性であった。術後 7 日目での エコー検査では, 明らかな異常は認めなかったが, 術 後 15 日目の検查では手術側の大腿静脈のカラーシグ ナルの久損像を認め, 血栓による血管内腔の狭窄を疑 わせる所見であった（図 1). 大伏在静脈のカラーシ グナルは非手術側が赤色を呈するのに比べ, 手術側は 黄色を呈して扔り，血流増加の所見であった（図 2).

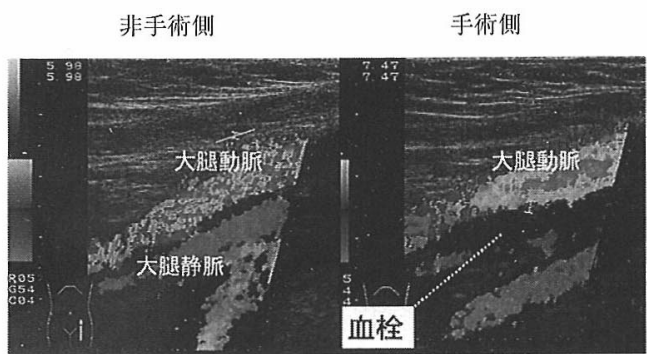

図 1 カラーモードでのDVT 診断 非手術側に比べ, 手術側では大腿静脈のカラー シグナルの欠損像を認め, 血栓による血管内腔 の狭窄を疑わせる所見を認めた.

非手術側

手術側

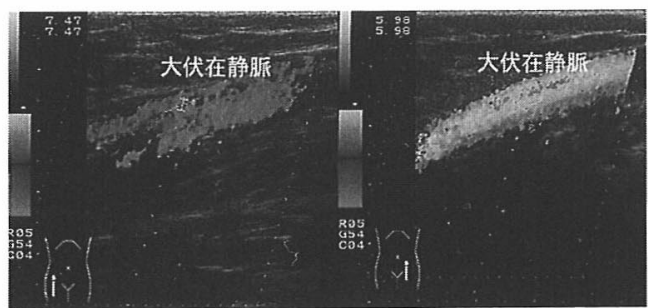

図 2 大伏在静脈の血流所見

大伏在静脈のカラーシグナルは非手術側が赤色 を呈するのに比べ, 手術側は黄色を呈しており, 血流増加の所見であった。

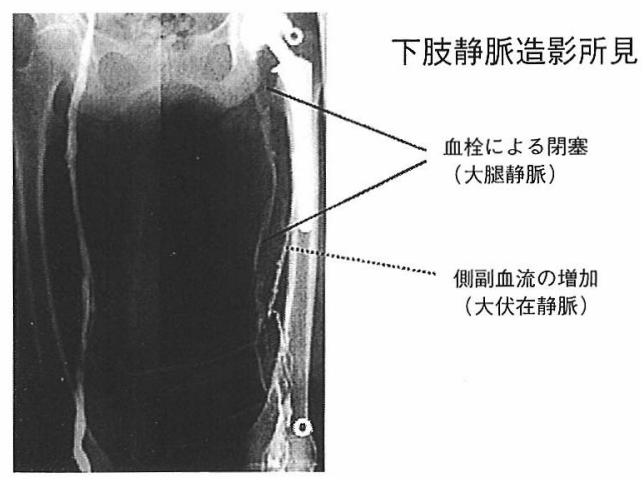

図 3 下肢静脈造影検查所見

下肢静脈造影検查では，左大腿静脈は近位部が 血栓による閉塞を生じている一方，側副血行路 として大伏在静脈に造影剤が流入している所見 を認めた。 
この症例に対し，下肢静脈造影検査を施行したところ， 大腿静脈は近位部が血栓による閉塞を生じている一方， 側副血行路として大伏在静脈に造影剤が流入している 所見を認めた（図 3). 我々は，このような大伏在静 脈の血流増加の所見を術後に認めた場合, DVTの発 症を示唆するものと考え, retrospectiveに対象症例 を検討した。

\section{結果}

術後 2 回の検査を行い大伏在静脈血流の増加を下肢 エコー検査のカラーモードで認めた例を大伏在静脈血 流増加ありと判定した。結果は 108 人 216 肢中, 39 人 $(36 \%) 49$ 肢 $(23 \%)$ に認め, その内訳は, 手術 側が 108 肢中 32 肢 $(30 \%)$ ，非手術側が 108 肢中 17 肢 $(16 \%)$ であった。両側例は 9 人 $(8 \%)$ であった. これらの症例は, Homans 徵候, Lowenberg test が陰性であり，胸痛や呼吸困難症状などがなかったた めに下肢静脈造影検査で DVT の有無を確認してはい ない.

検査時期による頻度では, 術後 5 8 日での増加は 24 肢, 術後 12 15 日での増加は 25 肢であるが, 2 回 とも増加を示したのは 5 肢であり, 約 1 週間で血流増 加状態は改善されることが推察された。

疾患による内訳は，変形性関節症 73 例中 21 例 $(29$ $\%)$ ，大腿骨頭壊死症 22 例中 9 例 $(41 \%)$ ，慢性関節 リウマチ 10 例中 7 例 $(70 \%)$ ，頸部骨折 3 例中 2 例 (67\%) であった（表 1).

術式による内訳は, 人工関節手術群では 64 例中 30 例 $(47 \%)$ ，で認めたのに対し，骨切り術群では 44 例 中 9 例 $(20 \%)$ で認め, カイ二乗検定で有意差 $(\mathrm{P}<0.01)$ を認めた。 人工関節手術の内訳をみてみ ると, THR 群と TKR 群では, THR 46 例中 20 例 $(43 \%)$, TKR 18 例中 10 例 $(56 \%)$ で有意差はなかっ た。初回手術群と再置換手術群では, 初回手術 48 例 中 23 例 $(48 \%)$, 再置換術 16 例中 7 例 $(44 \%)$ と有 意差はなかった（表 2).

その他，性別，年齢， BMI，検査側，ターニケッ 卜使用の有無, 術中術後出血量, 臥床期間, 麻酔法で は有意差はなかった (表 3 )。このうち, 人工関節手 術群と骨切り術群の比較では性別, 年齢, BMI を説 明変数に加えたロジスティック多変量回㷌分析でも, 有意差（P<0.01）を認めた（表 4$)$.
表 1 疾患別の頻度

\begin{tabular}{lrrc}
\hline \hline & あり & なし & 症例数 \\
\hline 変形性関節症 & 21 & 52 & 73 \\
大腿骨頭壊死症 & 9 & 13 & 22 \\
慢性関節リウマチ & 7 & 3 & 10 \\
大腿骨䅡部骨折 & 2 & 1 & 3 \\
\hline 全症例 & 39 & 69 & 108 \\
\hline
\end{tabular}

表 2 人工関節手術の内訳

\begin{tabular}{llll}
\hline \hline & あり & なし & P 值 \\
\hline THR/TKR & $20 / 10$ & $26 / 8$ & N.S \\
初回/再置換術 & $23 / 7$ & $25 / 9$ & N.S \\
\hline
\end{tabular}

表 3 単変量解析結果

\begin{tabular}{lccc}
\hline \hline & あり & なし & $\mathrm{P}$ 值 \\
\hline $\mathrm{M} / \mathrm{F}$ & $9 / 30$ & $16 / 53$ & $\mathrm{~N} . \mathrm{S}$ \\
年齢 & $56 \pm 16$ & $54 \pm 15$ & $\mathrm{~N} . \mathrm{S}$ \\
$\mathrm{BMI}$ & $23.2 \pm 3.4$ & $23.4 \pm 3.6$ & $\mathrm{~N} . \mathrm{S}$ \\
$\mathrm{R} / \mathrm{L}$ & $29 / 20$ & $91 / 76$ & $\mathrm{~N} . \mathrm{S}$ \\
人工/骨切り術 & $30 / 9$ & $34 / 35$ & $\mathrm{P}<0.01$ \\
ターニケット有/無 & $10 / 29$ & $8 / 69$ & $\mathrm{~N} . \mathrm{S}$ \\
Total 出血量 $(\mathrm{ml})$ & $1096 \pm 690$ & $953 \pm 505$ & $\mathrm{~N} . \mathrm{S}$ \\
臥床期間 (日) & $10 \pm 6$ & $12 \pm 5$ & N.S \\
全身麻酔/硬膜外 & $1 / 38$ & $3 / 66$ & N.S \\
\hline
\end{tabular}

表 4 ロジステック回帰分析結果

\begin{tabular}{lrcccc}
\hline \multicolumn{1}{c}{ 変数 } & \multicolumn{2}{c}{ 係数 } & \multicolumn{1}{c}{ 標準誤差 カイ2 乗 } & P 值 & オッズ比 \\
\hline 性別 : M & 0.216 & 0.538 & 0.162 & 0.6873 & 1.242 \\
年齢 & -0.032 & 0.021 & 2.276 & 0.1314 & 0.968 \\
BMI & -0.039 & 0.065 & 0.351 & 0.5536 & 0.962 \\
種類 : 人工 & 1.968 & 0.682 & 8.326 & 0.0039 & 7.154 \\
\hline
\end{tabular}

OR for 種類：人工関節 $=7.154$ ( $95 \%$ 信頼区間 : $1.88-27.23$ )

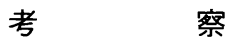

下肢静脈エコーによるDVT の診断方法は, B モー ドで血管の横断像を描出，プローブによる圧迫を加え， 静脈内腔の閉塞が得られるものを血栓なし, 閉塞不十 分なものを血栓ありと判定する方法が通常用いられる. 
さらにカラーモードに切り替えたのちに，カラーシグ ナルの久損を血栓ありの参考所見とするとしている ${ }^{1 / 31}$. このように血栓を直接確認する方法は, 膝窝静脈より 近位の大腿静脈に血栓が存在していれば比較的容易に 判定できるが，膝関節より遠位に存在するような場合 は判定が困難であり，さらに，TKRに比べ，THR 後に検査を行う場合は，股関節の脱臼に注意を払う必 要があるため, 座位, 腹臥位をとらせる必要のある遠 位部の下腿静脈の検査は容易ではない。事実，下肢工 コー検査による遠位下腿静脈血栓の診断 sensitivity は下肢造影検査の $12 \%$ にすぎないとの報告もある2!

一方佐藤らによれば, パルスドップラーモードを用い て, 大腿静脈のみを対象とした検索で, 深呼吸時や下 腿 milkingによる血流速変化の異常を血栓陽性の間 接所見とすることにより診断 sensitivity $87 \%$ を得 たとの報告 ${ }^{10}$ もある。

そこで今回我々は, 鼠径部の大伏在静脈の血流増加 でDVTを検索するという方法を用いることにより術 後 39 人 $(36 \%)$ にこの所見を得ることができた。こ の頻度は従来のエコー検査での DVT 診断率に比べる と頻度が高く，下肢静脈造影検査とほほ同等の検出率 が得られていると考えられる5!.さらに，この方法の 利点としては，被験者が仰臥位の状態のまま，短時間 で検査できることや読影が容易であることがあるが, この大伏在静脈の血流増加をきたす原因はDVTによ る深部静脈塞栓以外に, 動静脈瘻の存在, 静脈瘤など が考えられ, 今後は静脈造影検査との比較検討が必要 であると考える。

危険因子に関しての解析では，人工関節手術が骨切 り術より有意に頻度が高い傾向があっだ、本邦での報 告11では，肺塞栓症を術後合併した症例では骨盤骨切 り術がほとんどであったことより，DVTは骨切り術 がリスクが高いといわれるが，今回の検討では，性別， 年歯令, BMI で補正した多変量解析で比較しても人工 関節手術のほうがリスクが高い結果となった。この原 因としては，症例に大腿骨骨切り術が多く含まれてい たことや，エリスロポエチンを使用した自己血貯血の 影響を検討していないことがあげられる。ただし， 人工関節手術時の髄内操作により骨髄や脂肪が静脈内 へ流入し，心臓内を通過することが術中経食道心エコー で認められたとの報告 ${ }^{9}$ や，人工関節手術に伴う脱臼
操作による血管のねじれが血管壁を損傷するとの報告 もあり ${ }^{81}$ ，人工関節手術と骨切り術でどちらが DVT のリスクが高いかは，さらなる検討が必要であろう。

$$
\text { 結語 }
$$

216 肢に対する整形外科手術後の血行動態の変化に ついて，エコーを用い検討を加えた。 大伏在静脈の血 流増加は 39 人 $(36 \%) 49$ 肢 $(23 \%)$ の頻度で認め, ロジスティック回帰分析の結果, 骨切り術に比べ人工 関節置換術がそのリスクを高めると考えられた。

\section{参 考 文 献}

1) Andrew, N., Evi, K.: Duplex scanning in postoperative surgical patients. Haemostasis, $23: 72-79$, 1993.

2) Ciccone, W.J. et al.: Ultrasound surveillance for asymptomatic deep venous thrombosis after total joint replacement. J Bone Joint Surg, 80A : 11671174, 1998.

3）福世曲紀ほか：超音波検榃を用いた股関節于術後の深 部静脈血栓拉:の発生頻度. Hip Joint, $25: 86-88,1999$.

4）富:武火ほか：エリスロポエチン併用瞻血式向し片輸 向が深部静脈向栓症の発生頻度にな゙ Joint, $25: 82-85,1999$.

5）藤田悟ほか：人「関節全置換術後の深部静脈组栓将: の検討. Hip Joint, $25:$ 98-101, 1999.

6) Gardy-Benson, J.C. et al.: Postoperative surveillance for deep venous thrombosis with duplex ultrasonography after total knee arthroplasty. J Bone Joint Surg, 76A : 1649-1657, 1994.

7) Lieberman, J. R. et al.: Current concept review prevention of venous thromboem bolism after total hip and knee arthroplasty. J Bone Joint Surg, 76A : 1239-1250, 1994.

8) Planes, A. et al.: Total hip replacement and deep vein thrombosis. A venographic and necropsy study. J Bone Joint Surg, 72B : 13-19, 1990.

9) Rocco, P. P. et al.: Prophylaxis of fat and bone marrow embolism during total hip arthroplasty can reduce the prevalence of postoerative deep-vein thrombosis. AAOS abstruct, $67: 504,2000$.

10）珑藤洋ほか：大腿静脈を観察部位としたト肢深部静

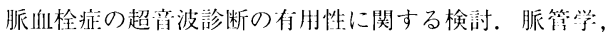
$37: 65-71,1997$.

11）柴山慶ほか：股関節乎術に命併した肺動脈血栓塞栓 症. 臨整外, $29: 999-1006,1994$.

12) Warwick, D. et al.: Death and thromboem bolic disease after total hip replacement. J. Bone and Joint Surg, 77B : 6-10, 1995. 